Vol.2, No. 1, Jan. 2019

\title{
PENGARUH PERTUMBUHAN EKONOMI DAERAH, PENDAPATAN ASLI DAERAH (PAD), DANA ALOKASI UMUM (DAU) DAN DANA BAGI HASIL (DBH) TERHADAP ALOKASI BELANJA MODAL DAERAH
}

\author{
Siti Mundiroh \\ Universitas Pamulang \\ Email : shetee_ballack13@hotmail.com
}

\begin{abstract}
The author's purpose is to prove whether the Capital Expenditures at Regency / City Governments in East Java in 2011-2014 is influenced by the variables of Regional Economic Growth and acceptance variables such as PAD, $D A U$ and DBH by analyzing and testing. The samples taken are those that meets certain criteria or conditions with a Purposive sampling method, where the population are data of the realization of Regency / City Government Regional Budget in East Java. The test tool used to test existing data is the classic assumption test and multiple linear regression analysis using SPSS version 24 for windows. From a series of tests conducted proved that partially both the independent variable Regional Economic Growth and DBH do not have a significant influence on Capital Expenditure, while the independent variable PAD and DAU have a significant influence on Capital Expenditures. However, together the four independent variables have a significant effect on the dependent variable, namely Capital Expenditures. The test is based on a confidence level of $95 \%$ and an error rate of $5 \%$.
\end{abstract}

Keywords: Regional Economic Growth, PAD, DAU, DBH and Capital Expenditure.

\begin{abstract}
Abstrak
Penulis mempunyai tujuan untuk dapat menganalisis, menguji dan kemudian membuktikan apakah Belanja Modal pada Pemda Kabupaten/Kota di Jawa Timur tahun 2011-2014 dipengaruhi oleh variabel Pertumbuhan Ekonomi Daerah serta variabel-variabel penerimaan seperti PAD, DAU dan DBH. Dasar pengambilan sample adalah sample yang memenuhi kriteria atau syarat tertentu dengan metode Purposive sampling, dimana populasinya adalah data realisasi APBD Pemda Kabupaten/Kota di Jawa Timur. Alat uji yang digunakan untuk menguji data yang ada adalah uji asumsi klasik dan analisis regresi linier berganda menggunakan SPSS versi 24 untuk windows. Dari serangkain pengujian yang dilakukan menghasilkan data yang dapat membuktikan bahwa secara parsial baik variabel bebas Pertumbuhan Ekonomi Daerah maupun DBH tidak berpengaruh
\end{abstract}


signifikan terhadap Belanja Modal, sementara itu variabel bebas PAD dan DAU mempunyai pengaruh siginifikan terhadap Belanja Modal. Namun demikian secara bersama-bersama keempat variabel bebas tersebut berpengaruh signifikan terhadap variabel terikat yaitu Belanja Modal. Pengujian tersebut berdasarkan pada tingkat keyakinan sebesar 95\% dan tingkat eror sebesar $5 \%$.

Katakunci :Pertumbuhan Ekonomi Daerah, PAD, DAU, DBH dan Belanja Modal.

\section{PENDAHULUAN}

Dalam rangka desentralisasi dimana Pemda diberikan hak dan wewenang yang besar dalam memanfaatkan sumber pendapatan seperti yang dijelasan dalam UU No. 32/2004 telah memberikan kesempatan pada Pemerintah Daerah untuk dapat memenuhi kebutuhannya dan juga menyerap aspirasi yang berkembang di masyarakat. Selain Pendapatan Asli Daerah (PAD), Pemerintah Daerah juga mempunyai sumber keuangan lain yaitu dana perimbangan yang diperoleh dari transfer APBN Pemerintah Pusat. Hal ini merupakan perwujudan dari apa yang tertuang dalam UU Nomor 33/2004 pasal 157. Ada 3 sumber dana dari pemerintah pusat yang diterima oleh Pemerinth Daerah, yaitu DAU yang merupakan kependekan dari Dana Alokasi Umum, kemudian DAK yang merupakan kependekan dari Dana Alokasi Khusus dan juga DBH yang merupakan kependekan dari Dana Bagi Hasil. DBH itu sendiri terdiri dari dua alokasi, yaitu $\mathrm{DBH}$ yang bersumber dari pendapatan pajak dan $\mathrm{DBH}$ yang bersumber dari pendapatan non pajak atau pengelolaan sumber daya daerah tersebut. Dengan kata lain, melalui otonomi daerah, Pemerintah Daerah diberi kewenangan penuh guna mengatur keuangannya sendiri. Adapun anggaran yang diberikan oleh Pemerintah Pusat hanya bersifat bantuan atau tambahan saja.

Tingkat pertumbuhan ekonomi yang baik tentu saja merupakan sesuatu yang sangat dicita-citakan oleh Pemerintah Pusat dan Pemerintah Daerah. Senada dengan pertumbuhan ekonomi, pembangunan ekonomi juga sangat diharapakan dapat tercapai. Adapun indikasi dari pembangunan ekonomi adalah peningkatan produktivitas serta pendapatan perkapita yang berujung pada peningkatan kesejahteraan. Dalam usaha peningkatan pembangunan ekonomi, Pemerintah berupaya mengelola sumber daya dengan sebaik mungkin melalui berbagai cara, salah satunya dengan cara bermitra dengan masyarakat guna membuka lapangan pekerjaan baru di daerah tersebut. Pada umumnya, peningkatan pertumbuhan ekonomi akan diikuti oleh peningkatan belanja modal meskipun terkadang jumlahnya tidak terlalu signifikan.

Peningkatan pelayanan publik merupakan hal yang sesungguhnya ingin dicapai oleh pemerintah daerah otonom guna menarik minat calon penanam modal untuk berinvestasi di daerah tersebut. Untuk mewujudkannya Pemerintah harus dapat menyediakan fasilitas yang memadai. Tentu saja untuk membangn fasilitas (sarana dan prasarana) yang dimaksud membutuhkan pembiayaan yang 
jumlahnya tidak sedikit. Oleh karena itulah, masyarakat sangat mengharapkan agar Pemda memberikan porsi dana yang lebih besar guna pembelanjaan modal. Namun demikian, menurut Keefer dan Khemani (2003) dalam Putro (2010) adanya perbedaan kepentingan golongan maupun politik yang dimiliki oleh oknum anggota penyusunan anggaran seringkali menyebabkan distorsi alokasi belanja modal.

Jika dilihat dari laporan yang ada, alokasi belanja daerah masih kurang produktif karena sebagian besar anggaran yang ada dilaokasikan untuk membiayai kebutuhan rutin (gaji pegawai, honor dsb) sedangkan untuk Belanja Modal hanya sejumlah kecil anggaran saja yang dialokasikan. Diharapkan agara alokasi belanja lebih banyak dialokasikan untuk pembangunan sarana dan prasana guna peningkatan kualitas pelayanan publik. Masyarakat mengharapkan adanya fasilitas dari pemerintah untuk melakukan aktivitas-aktivitas yang dilakukan dalam upaya peningkatan perekonomian. Adapun cara yang mungkin dapat dicoba adalah dengan menambah peluang untuk investasi, pembangunan infrastruktur dan fasilitas lainnya yang dapat memberikan kemudahan serta daya tarik investasi bagi calon investor, dengan demikian Pendapatan Asli Daerah (PAD) pun akan mengalami peningkatan.

Efisiensi dan efektivitas dalam pengelolaan APBD merupakan faktor yang sangat mempengaruhi keberhasilan pengelolaan APBD daerah tersebut. Jika Pemda mampu mengelola APBD secara efektif dan efisien maka akan terwujud peningkatan pembangunan daerah dan juga peningkatan kesejahteraan rakyat. Namun jika Pemda kurang mampu dan kurang efisen dalam praktek pengelolaan APBD maka justru akan menghambat kinerja Pemda untuk meningkatkan pembangunan serta kesejahteraan rakyat. Masalah yang seringkali dihadapi oleh Pemda adalah jumlah PAD yang kecil dengan tanggungan kebutuhan yang besar. Ditambah lagi kuranganya kreativitas Pemda dalam pengelolaan APBD yang akan berimbas pada pemerintah di atasnya; misal Pemprov dan Pemerintah Pusat yang harus menambah porsi dana perimbangan untuk daerah tersebut. Persoalan lainnya yang berkenaan dengan belanja modal adalah ketika penerimaan daerah baik yang berumber dari PAD, DAU maupun DBH yang bertambah namun tidak sejalan dengan peningkatan jumlah alokasi belanja modal sehingga infrastruktur yang dibutuhkan oleh masyarakat belum juga terealisasi. Hal ini menunjukan bahwa Pemda masih kurang berkomitmen terhadap upaya perbaikan nilai pelayanan publik melalui pengembangan dan pembangunan infrastruktur yang dibutuhkan masyarkat guna pembangunan ekonomi.

Adapun dilakukannya penelitian ini adalah dengan maksud guna menguji pengaruh Pertumbuhan Ekonomi, PAD, DAU dan DBH terhadap alokasi Belanja Modal. Diharapkan hasil penelitian ini dapat menerangkan: (1) Apakah Pertumbuhan Ekonomi Daerah berpengaruh terhadap alokasi Belanja Modal? (2) Apakah PAD berpengaruh terhadap alokasi Belanja Modal? (3) Apakah DAU berpengaruh terhadap alokasi Belanja Modal? (4) Apakah DBH berpengaruh terhadap alokasi Belanja Modal? (5) Apakah secara simultan keseluruhan variabel bebas yaitu Pertumbuhan Ekonomi, PAD, DAU dan DBH mempunyai pengaruh terhadap alokasi Belanja Modal? 
Vol.2, No. 1, Jan. 2019

\section{KERANGKA TEORITIS DAN PENGEMBANGAN HIPOTESIS}

\section{Otonomi Daerah}

Seperti dijelaskan dalam UU No. 32/2004 Pasal 1 (5) mengenai Pemerintahan Daerah yang dapat ditafsirkan bahwa melalui pelaksanaan otonomi daerah maka suatu daerah mempunyai hak, wewenang, serta kewajiban guna mengelola urusan pemerintahan (mengelola pendapatan dan pengeluaran) secara mandiri dengan hanya sedikit support dari Pemerintah pusat yang berupa dana perimbangan. Sejalan adanya wewenang yang diberikan pada Pemda, Pemda juga mempunyai kewajiban untuk menyerap aspirasi dan apa yang menjadi kebutuhan masyarakat dimana sesuai undang-undang yang ada. Desentralisasi merupakan asas yang diterapkan dalam otonomi daerah dimana Pemda diberikan keleluasaan dalam mengelola urusan pemerintahan dengan sedikit bantuan dari Pemerintah Pusat. Pemda diberikan kewenangan untuk dapat menggali sumber-sumber pendapatan baru guna membiayai kebutuhannya.

\section{Hubungan Antara Pertumbuhan Ekonomi dengan Belanja Modal}

Melalui desentralisasi fiskal diharapkan Pemda dapat mengoptimalkan sumber penerimaan yang ada guna mendorong peningkatan ekonomi daerah tersebut. Pernyataan ini sejalan dengan teori federalism. Seperti yang sudah disebutkan sebelumnya bahwa asas desentralisasi yang diberlakukan dalam otonomi daerah memberikan kewenangan pada Pemda untuk dapat menggali sumber-sumber pendapatan baru, dengan asumsi Pemda berhasil untuk melakukannya, maka seharusnya Pemda dapat secara mandiri membiayai pengeluarannya, baik pengeluaran yang bersifat rutin maupun pengeluaran untuk belanja modal. Belanja modal yang dimaksud adalah pembangunan infrastruktur untuk pelayanan publik dan menarik minat para calon investor. Selain penting untuk pembangunan ekonomi, pembangunan fasilitas publik juga merupakan sebuah bentuk pertanggungjawaban Pemda terhadap masyarakat yang sudah berkontribusi dengan membayar pajak. Berdasarkan paparan tersebut dapat dirumuskan Hipotesis seperti dibawah ini:

$\mathrm{Ha}_{1}=$ Pertumbuhan Ekonomi Daerah berpengaruh terhadap Belanja Modal di Pemerintah Kabupaten/Kota di Provinsi Jawa Timur.

\section{Hubungan Antara PAD dengan Belanja Modal}

Pendapatan daerah yang cukup krusial adalah PAD seperti yang disebutkan oleh Ardhani (2011). Pendapatan ini bersumber dari pungutan pajak daerah, retribusi serta hasil pengelolaan kekayaan sumberdaya yang dimiliki oleh daerah tersebut. Oleh karenanya daerah otonom diharapkan mampu untuk meningkatkan PAD dengan cara mengoptimalkan sumberdaya yang ada guna meningkatkan pembangunan infrastruktur bagi masyarakat melalui alokasi belanja modal. Diharapkan agar peningkatan PAD akan dapat sejalan dengan peningkatan alokasi belanja modal guna pembangunan. Selain itu, jumlah PAD yang diperoleh oleh suatu daerah juga mempangaruhi seberapa besar kewenangan daerah tersebut untuk dapat menerapkan kebijakannya. Agar daerah dapat dengan leluasa membangun berbagai sarana prasarana, maka Pemda dituntut untuk dapat 
meningkatkan penerimaannya yang bersumber dari PAD. Merujuk pada paparan tersebut, maka kemudian dikembangkan Hipotesis seperti di bawah ini:

\section{$\mathrm{Ha}_{2}=$ Pendapatan Asli Daerah (PAD) berpengaruh terhadap Belanja Modal} di Pemerintah Kabupaten/Kota di Provinsi Jawa Timur.

\section{Hubungan Antara DAU dengan Belanja Modal}

Selain desentralisasi, dalam pelaksanaan otonomi daerah juga menerapkan dekonsentrasi serta pembantuan yang diberikan oleh Pemerintah Pusat. Seperti yang sudah dijelaskan sebelumnya, dalam desentralisasi Pemerintah Pusat memberikan wewenang pada Pemda untuk dapat menggali sumberdaya yang potensial yang ada di daerah tersebut guna menunjang pembiayaan. Namun demikian, pada kenyataanya Pemda seringkali tidak dapat hanya mengandalkan PAD-nya saja, seringkali Pengeluarannya jauh lebih banyak dari PAD yang mereka terima. Oleh karena itu, Pemerintah Pusat membantu Pemda untuk memenuhi kebutuhannya melalui dana perimbangan yaitu DAU. Tujuan diberikannya DAU adalah guna pengurangan kesenjangan kemampuan finansial antara Pemerintah Pusat dengan Pemda sesuai dengan UU Nomor 33/2004. Diharapkan agar peningkatan alokasi belanja modal daerah dapat terwujud sejalan dengan bertambahnya penerimaan yang berasal dari APBN ini. Dengan demikian dapat dikembangkan Hipotesis sebagai berikut:

$\mathrm{Ha}_{3}$ = Dana Alokasi Umum (DAU) berpengaruh terhadap Belanja Modal di Pemerintah Kabupaten/Kota di Provinsi Jawa Timur.

\section{Hubungan Antara DBH dengan Belanja Modal}

Dalam praktek desentralisasi, Pemerintah Pusat memberikan dana kepada masing-masing Pemda yang selanjutnya disebut dana perimbangan. Salah satu dari dana perimbangan tersebut adalah DBH dimana alokasi yang ditransfer oleh Pemerintah Pusat (APBN) dihitung berdasarkan presentase tertentu seperti yang tertuang dalam UU No 33/2004. Ada dua jenis DBH yang diberikan oleh Pemerintaah Pusat yaitu DBH yang berasal dari pendapatan berupa pajak dan DBH yang bukan berasal dari pendapatan berupa pajak (SDA). Adapun bagi hasil yang berasal dari pajak adalah PPh orang Pribadi, yaitu PPh 21 dan PPh 25/29 Orang Pibadi. Pemberian DBH yang berasal dari pajak bertujuan untuk membantu daerah yang tidak mempunyai SDA potensial namun mempunyai peran yang cukup baik bagi pedapatan negara. Karena sistem pemberian DBH adalah presentase, maka daerah yang mempunyai basis pajak yang besar akan memperoleh DBH yang besar pula.

Selain PAD dan DAU, DBH juga merupakan penerimaan yang cukup potensial. Dengan adanya dana perimbangan DBH ini diharapkan Pemda dapat mengoptimalkan pembangunan sarana dan prasarana untuk kepentingan publik. Secara teoritis, Pemda dapat meningkatkan alokasi belanja modal sejalan dengan peningkatan DBH yang diterima dari Pemerintah Pusat. Sebaliknya, sejalan dengan semakin kecil DBH yang didapat oleh Pemda, maka anggaran Belanja Modal yang dialokasikan oleh Pemda tersebut juga akan mengalami penurunan. Merujuk pada paparan di atas, maka kemudian dikembangkan Hipotesis sebagaimana berikut ini: 
$\mathrm{Ha}_{4}=$ Dana Bagi Hasil $(\mathrm{DBH})$ berpengaruh terhadap Belanja Modal di Pemerintah Kabupaten/Kota di Provinsi Jawa Timur.

\section{Hubungan antara Pertumbuhan Ekonomi Daerah, PAD, DAU dan DBH terhadap Belanja Modal}

Melalui otonomi daerah dan desentralisasi maka diharapkan daerah otonom dapat mandiri dalam mengelola pengeluarannya. Dalam hal Belanja Modal, Pemerintah Daerah diharpkan mampu mengelolanya dengan seefektif fan seefisien mungkin dengan memperhatikan faktor-faktor seperti Pertumbuhan Ekonomi Daerah, PAD, DAU serta DBH. Pemda diharapkan dapat senantiasa meningkatkan pembangunan infrastruktur melalui alokasi Belanja Modal agar dapat meningkatkan pelayanan dan kepuasan publik. Untuk dapat mewujudkannya Pemda diharapkan mampu menggali terus potensi sumber daya yang terdapat di daerahnya masing-masing agar pemasukan Pemda terus meningkat yang mana hal ini akan dapat meningkatkan alokasi Belanja Modal. Dengan demikian, maka kemudian dikembangkan hipotesis berikut ini:

$\mathrm{Ha}_{5}=$ Pertumbuhan Ekonomi Daerah, Pendapatan Asli Daerah (PAD), Dana Alokasi Umum (DAU) dan Dana Bagi Hasil (DBH) secara simultan berpengaruh terhadap Belanja Modal di Pemerintah Kabupaten/Kota di Provinsi Jawa Timur.

\section{Kerangka Berfikir}

Berdasarkan kajian pustaka mengenai Pertumbuhan Ekonomi Daerah, PAD, DAU dan DBH, maka dapat dipetakan kerangka berfikir untuk penelitian yang penulis lakukan seperti ilustrasi di bawah ini:

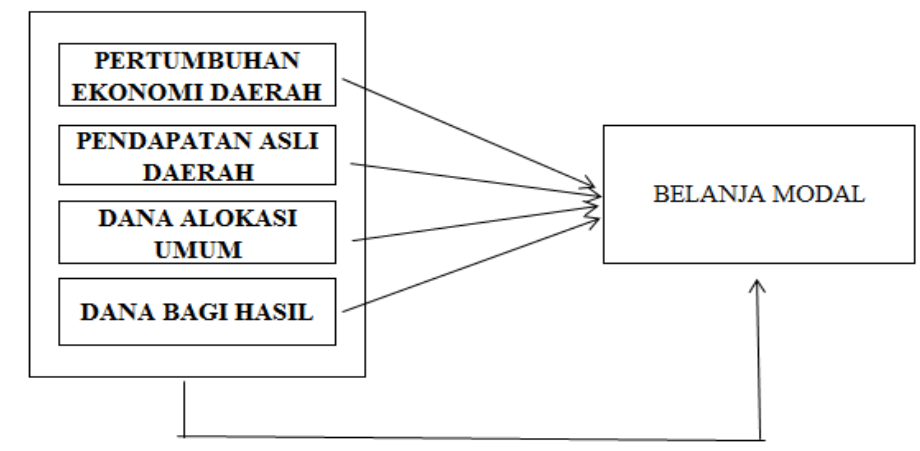

Gambar 1 : Kerangka Berfikir

\section{METODE PENELITIAN}

\section{Desain Penelitian dan Sumber Data}


Menilik dari tujuan dari penelitian ini dimana tujuan yang ingin dicapai adalah untuk mendapat penjelasan atas gejala yang disebakan oleh objek penelitian, maka penelitian yang penulis lakukan ini bisa digolongkan ke dalam penelitian explanatory kausalitas. Dengan kata lain penelitian ini mempunyai tujuan untuk menerangkan hubungan kausalitas antara variabel-variabel bebas dengan variabel terikat yang menjadi objek penelitian melalui serangkain pengujian hipotesis yang ada. Metode penelitian kuantitatif merupakan metode penelitian yang penulis gunakan dalam melakukan penelitian. Data yang telah didapat dan disusun disajikan dalam bentuk angka dan skor, kemudian dianalisis menggukan statistika. Adapun sumber data dari penelitian yang penulias lakukan merupakan sumber data sekunder yang diunduh dari website Dirjen Perimbangan Keuangan Pemda. Adapaun data yang dimaksud adalah (1) Laporan Pertumbuhan Ekonomi Jawa Timur dan (2) Laporan Realisasi APBD Pemerintah Daerah Kabupaten/Kota di Provonsi Jawa Timur Tahun 2011-2014, yang terdiri dari data (3) realisasi PAD, (4) realisasi DAU, (5) realisasi $\mathrm{DBH}$, dan (6) data realisasi belanja modal.

\section{Populasi dan Sampel}

Pemerintah Daerah Kabupaten/Kota di Provonsi Jawa Timur Tahun 20112014 merupakan populasi yang digunakan dalam penelitian yang penulis lakukan, yang kemudian sebagian besar dari populasi tersebut dijadikan sampel. Adapun Purposive Sampling merupakan metode pengumpulan sampel yang digunakan dalam melakukan penelitian dimana seleksi sampel dilakukan dengan menggunaka kriteria tertentu. Dasar pengambilan sampel adalah kriteria mengenai kelengkapan data (kontinuitas), jika terdapat data dari populasi tersebut yang tidak lengkap, maka data tersebut tereliminasi dan tidak bisa digunakan sebagai sampe penelitian.

\section{Metode Ananlisis Data Analisis Deskriptif}

Analisis deskriptif merupakan analisis yang dipergunakan untuk menerangkan hubungan antara variabel bebas Pertumbuhan Ekonomi Daerah, PAD, DAU, DBH, dan variabel terikat belanja modal. Untuk melakukan analisis ini penulis menggunakan statistik. Gambaran atau informasi yang didapat dari hasil analisis ini adalah seberapa besar mean atau nilai average, nilai maximum, nilai minimum dan juga besaran standar deviasi dari masing-masing variabel.

\section{Uji Asumsi Klasik}

Dikarenakan oleh penggunaan data sekunder oleh penulis dalam melakukan penelitian ini, maka wajib sifatnya dilakukan uji asumsi klasik. Uji asumsi klasik ini dilakukan dalam upaya memperoleh model regresi yang tepat Adapun tujuan dari dilakukannya uji asumsi klasik adalah guna memastikan kelayakan penggunaan model regresi dalam penelitian. Selain itu, dilakukannya pengujian asumsi klasik juga guna memastikan tidak adanya multikolinieritas, heterokedasitas, auto-korelasi dalam model regresi serta memastikan bahwa data yang digunakan sudah memenuhi syarat normalitas. Langkah selanjutnya setelah 
melakukan uji asumsi klasik adalah uji regresi linier berganda. Berikut merupakan langkah-langkah dalam uji asumsi klasik:

\section{Uji Normalitas Data}

Dilakukannya uji normalitas data merupakan langkah yang sangat penting, karena melalui uji normalitas data dapat membantu penulis dalam memastikan pendistribusian variabel-variabel penelitian serta sudah sesuaikah model regresi yang digunakan. Dari hasil uji normalitas data dapat dilihat apakah pendistribusian variabel-variabel penelitian sudah normal atau tidak. Seperti yang sudah diketahui bahwa data yang pendistribusiannya normal ataupun mendekati normal mencerminkan bahwa model regresi yang digunakan sudah sesuai. Sebaliknya, apabila data tidak berdistribusi secara normal artinya model regresi yang digunakan masih belum sesuai. Alat untuk melakukan uji normalitas terhadap masing-masing variabel pada penelitian adalah kolmogorov smirnov. Selain itu juga menggunakan Plot of Regression Standardlized Residual variabel independen. Untuk menilai normalitas data dari hasil P Plot of Regression Standardlized adalah dengan melihat arah sebaran titik-titiknya, jika titik-titik tersebut tersebar sejalan atau searah garis diagonal, maka dapat dinyatakan bahwa model regresi sudah sesuai dan memenuhi ketentuan normalitas. Sebaliknya, suatu model regresi dapat disimpulkan tidak memenuhi syarat normalitas apabila titik-titik tersebar tidak disekitar garis diagonal ataupun tidak sejalan atau searah garis diagonal,

\section{Uji Multikolinieritas}

Terkadang dalam sebuah model regresi terdapat kemiripan antar variabel independen. Oleh karena itulah diperlukan dilakukannya uji multikolinieritas untuk memastikan bahwa tidak ada kemiripan tersebut dalam model yang digunakan untuk penelitian ini. Disamping itu, dilakukannya uji multikolinieritas juga agar keputusan yang diambil perihal pengaruh variabel-variabel bebas terhadap variabel terikat tidak bias. Untuk memastikan suatu model mengandung multikolinieritas atau tidak bisa dilihat dari nilai Variance Inflation Factor (VIF) dan nilai Tolerance. Suatu model dapat disimpulkan tidak mengandung multikolinieritas apabila nilai VIF maksimal 10 dan nilai Tolerance minimal 0,1.

\section{Uji Autokorelasi}

Sebuah model yang baik harus terbebas dari autokorelasi antara kesalahan pengganggu periode tertentu dengan kesalahan pengganggu periode sebelumnya, oleh karena itulah diperlukan adanya uji Autokorelasi. Apabila terdapat korelasi, maka disebut ada masalah autokorelasi dalam model tersebut. Adapun autokorelasi itu sendiri disebakan oleh adanya penelitian yang saling berhubungan antara satu penelitian dengan penelitian lainnya, dan atau penelitian yang dilakukan secara beruntun sepanjang waktu. Penulis menggunakan alat test Durbin Watson (DW Test) untuk melakukan uji Autokorelasi dalam penelitian yang dilakukan. Sebagaimana tujuan pengujian Autokorelasi, uji menggunakan DW Test ini dilakukan untuk menguji adakah korelasi berurutan atau tidak. Hal ini dilakukan dengan cara menghitung nilai $d$ statistik. Dari hasil DW Test dalam 
suatu model dapat dilihat apakah terdapat Autokorelasi atau tidak. Suatu model dapat disimpulkan mengandung Autokorealasi apabila nilai DW berada pada rentang -2 sampai dengan +2 . Sebaliknya, dikatakan terdapat autokorelasi dalam suatu model jika nilai DW diluar batas -2 sampai +2 .

\section{Uji Heteroskedasitas}

Uji Heteroskedasitas mempunyai tujuan guna menguji apakah terdapat perbedaan varians dalam model regresi dari residual suatu observasi ke observasi lainnya. Adapun yang dimaksud dengan Homoskedasitas adalah apabila terdapat nilai yang sama antara varians residual suatu penelitian dengan varians residual penelitian lainnya. Sedangkan yang dimaksud dengan Heteroskedasitas adalah apabila nilai varians residual suatu penelitian selalu berbeda dengan varians residul penelitian lainnya. Dengan kata lain, jika ada kesamaan nilai varians residual dari beberapa penelitian menunjukan adanya Homoskedasitas, dan jika tidak terdapat persamaan nilai antar varians residul penelitian maka terdapat Heteroskedasitas. Adapun suatu model regresi dinyatakan baik apabila model regresi tersebut mengandung Homoskedastisitas atau tidak mengandung Heteroskedastisitas. Uji Scatterplot merupakan alat uji statistik yang dipergunakan dalam penelitian yang dilakukan penulis guna memastikan apakah model regresi yang diuji mengandung Heteroskedasitas atau tidak. Untuk memastikan apakah model regresi yang diuji mengandung Heteroskedasitas atau tidak dapat dilihat dari grafik plot yaitu dari nilai ZPRED dan SRESID. ZPRED adalah nilai dari variabel dependen sedangkan SRESID merupakan nilai residualnya. Penentuan apakah terjadi Heteroskedasitas dalam model regresi yang diuji bisa dilihat dari ada atau tidaknya pattern tertentu pada grafik Scatterplot antara SRESID dan ZPRED. Adapun Sumbu Y merupakan Y yang sudah diperkirakan, dan sumbu $\mathrm{X}$ adalah nilai sisa dari $\mathrm{Y}$ perkiraan diambil $\mathrm{Y}$ yang sesungguhnya yang telah di studentized. Suatu model regresi dapat disimpulkan mengandung Heteroskedasitas apabila terdapat pola tertentu dalam grafik scatterplot. Namun jika tidak terdapat pola-pola tertentu dalam grafik scatterplot maka dapat dipastikan bahwa model regresi yang diuji tidak mengandung Heteroskedasitas. Selain itu data juga dianalisis menggunakan uji Glesjer. Uji Glesjer meregres nilai absolut residual terhadap variabel independen dengan persamaan regresi $U t=\alpha+\beta X t+v t$. Suatu model regresi dapat dikatakan terbebas dari Heteroskedasitas apabila tingkat probabilitas signifikansinya diatas tingkat kepercayaan $5 \%(\alpha=0,05)$.

\section{Analisis Regresi}

Analissi regresi merupakan tahap pengujian selanjutnya, setelah dilakukannya uji asumsu klasik. Adapun langkah-langkah analisis regresi terdiri dari:

1. Model Regresi

Untuk menguji masing-masing Hipotesis yang dikemukakan digunakan metode regresi linier berganda. Maksud dari dilakukannya pengujian regresi linier berganda adalah guna menguji kandungan variabel bebas antara lain Pertumbuhan Ekonomi, PAD, DAU, dan DBH terhadap variabel terikat yaitu 
belanja modal. Hal ini dilakukan dengan melihat kekuatan korelasi antara variabel terikat dengan variabel bebas. Bentuk model regresi linier berganda tersebut dapat dirumuskan sebagai berikut:

$\mathrm{Y}=\mathrm{a}+\mathrm{b}_{1} \mathrm{X}_{1}+\mathrm{b}_{2} \mathrm{X}_{2}+\mathrm{b}_{3} \mathrm{X}_{3}+\mathrm{b}_{4} \mathrm{X}_{4}+\mathrm{e}$

Keterangan :

$\mathrm{Y}=$ Belanja Modal

A $\quad=$ Konstanta

$\mathrm{b}_{1} \mathrm{~b}_{2} \mathrm{~b}_{3} \mathrm{~b}_{4}=$ Koefisien Regresi untuk $\mathrm{X}_{1}, \quad \mathrm{X}_{2}, \mathrm{X}_{3}$, dan $\mathrm{X}_{4}$

$\mathrm{X}_{1} \quad=$ Pertumbuhan Ekonomi

$\mathrm{X}_{2} \quad=$ Pendapatan Asli Daerah (PAD)

$\mathrm{X}_{3} \quad=$ Dana Alokasi Umum (DAU)

$\mathrm{X}_{4} \quad=$ Dana Bagi Hasil $(\mathrm{DBH})$

e $\quad=$ Faktor lain (Faktor Pengganggu)

2. Mencari Koefisien Determinasi

Pengujian regresi berganda dilakukan untuk memperoleh nilai Koefisien Determinasi $\left(\mathrm{R}^{2}\right)$ dan koefisien determinan parsial $\left(\mathrm{r}^{2}\right)$. Nilai Koefisien Determinasi $\left(\mathrm{R}^{2}\right)$ yang diperoleh kemudian dimanfaatkan guna menguji sejauh mana model regresi tersebut dapat menerangkan kontribusi variabel bebas terhadap variabel terikat. Apabila nilai $\mathrm{R}^{2}$ mendekati 1 , maka bisa disimpulkan bahwa model regresi yang digunakan dapat dengan kuat menerangkan kontribusi variabel bebas terhadap variabel terikat. Koefisien determinan parsial yang dilambangkan dengan $\left(\mathrm{r}^{2}\right)$ adalah nilai dari masingmasing variabel independen. Dari nilai koefisien determinan parsial inilah dapat diketahui seberapa besar kontribusi positif yang disalurkan oleh masing-masing variabel bebas terhadap variabel terikat. Suatu variabel bebas dinyatakan memberikan kontribusi yang besar terhadap variabel terikat jika nilai koefisien determinan parsial dari variabel independen tersebut menunjukan nilai yang cukup besar. Dengan kata lain, nilai koefisien determinan mencerminkan seberapa besar kontribusi variabel bebas terhadap variabel terikat.

3. Uji Statistik F

Pengujian Statistik F dilakukan dengan tujuan guna mengetahui pengaruh keseluruhan variabel bebas secara bersama-sama atau simultan terhadap variabel terikat. Untuk mengambil kesimpulan dari hasil Uji $\mathrm{F}$ dapat dilakukan dengan melihat hasil $F_{\text {hitung }}$ dan $F_{\text {table. }}$. Apabila $F_{\text {hitung }}<F_{\text {tabel }}$, maka Ha ditolak, yang dapat diartikan bahwa tidak terdapat pengaruh antara Pertumbuhan Ekonomi, PAD, DAU, dan DBH terhadap belanja modal. Ha dikatakan diterima jika $F_{\text {hitung }}>F_{\text {tabel }}$, artinya terdapat pengaruh antara Pertumbuhan Ekonomi, PAD, DAU dan DBH terhadap belanja modal.

4. Uji Statistik t

Apabila Uji Statistik F dilakukan guna mengetahui apakah secara bersama-sama seluruh variabel bebas mempunyai pengaruh terhadap variabel terikat, maka Uji t dilakukan guna mengetahui apakah masing-masing variabel bebas tersebut mempunyai pengaruh terhadap variabel terikat. Adapun yang menjadi acuan dalam pengambilan keputusan dari Uji t adalah hasil nilai $\mathrm{t}_{\text {hitung }}$ dan $\mathrm{t}_{\text {tabel. }}$. Apabila $\mathrm{t}_{\text {tabel }}$ lebih besar dari $\mathrm{t}_{\text {hitung, }}$, maka Ho ditolak, 
yang berarti bahwa Pertumbuhan Ekonomi, PAD, DAU, dan DBH berpengaruh terhadap belanja modal. Namun jika $t_{\text {tabel }}$ lebih kecil dari $t_{\text {hitung, }}$ maka dapat disimpulkan Ha diterima, berarti bahwa Pertumbuhan Ekonomi, PAD, DAU, dan DBH tidak berpengaruh terhadap belanja modal.

\section{Definisi Operasional Variabel Variabel Dependen}

Secara sederhana, Belanja Modal dapat diartikan sebagi pembelenjaan langsung yang dilakukan Pemda untuk peningkatan pelayanan publik melalui pembelian asset dan pembangunan infrastruktur, sarana dan prasarana yang mendukung aktivitas masyarakat dalam perekonomian. Dalam penelitian ini, variabel Belanja modal adalah Belanja modal yang dilakukan oleh Pemda Kabupaten/Kota di Provinsi Jawa Timur. Adapun parameter untuk variabel belanja modal adalah sebagai berikut; Belanja Tanah, Belanja Peralatan dan Mesin, Belanja Gedung dan Bangunan, Belanja Jalan, Irigasi dan Jaringan, Belanja Aset Lainnya. Skala rasio merupakan skala pengukuran yang dipergunakan dalam mengukur variabel belanja modal.

\section{Variabel Independen}

\section{Pertumbuhan Ekonomi (X1)}

Seperti yang dijelaskan oleh Boediono (1985) dimana Pertumbuhan Ekonomi merupakan suatu proses peningkatan output perkapita serta merupakan suatu ukuran kuantitatif yang mencerminkan peningkatan perekonomian daerah dalam suatu periode tertentu. Semakin tinggi output perkapita suatu daerah, semakin baik pertumbuhan ekonominya, sebaliknya semakin rendah output perkapita semakin rendah pula tingak pertumbuhan ekonomi daerah tersebut.

2. PAD (X2)

PAD merupakan sumber keuangan Pemerintah Daerah yang berasal dari internal kawasan daerah tersebut. PAD berasal dari hasil pajak daerah, retribusi daerah, hasil pengelolaan kekayaan daerah yang dipisahkan, dan pendapatan daerah lainnya yang sah. Adapun parameter variabel PAD adalah sebagai berikut: pajak daerah, retribusi daerah, hasil BUMD dan hasil pengelolaan kekayaan daerah yang dipisahkan, pendapatan daerah lainnya yang sah. Dengan kata lain, PAD merupakan pendapatan murni suatu daerah, pendapatan yang merupakan hasil kontribusi dari masyarakat dan sumber daya daerah itu sendiri. Banyak daerah yang bergantung pada PAD untuk pembiayaan kebutuhannya, namun demikian tidak sedikit juga daerah yang kurang bisa bergantung dari PAD karena kurangnya SDA atau potensi penerimaan dari sektor pajak daerah. PAD setiap daerah tentunya berbedabeda, karena kekayaan dan potensi pendapatan yang terdapat pada masingmasing daerah berbeda-beda pula. Oleh karena itu diharapkan agar masingmasing daerah dapat terus menggali potensi-potensi penerimaan yang ada dengan mengeksplor sumber daya yang ada serta meningkatan potensi pajak daerah. Skala rasio merupakan skala pengukuran yang digunakan untuk variabel PAD.

\section{DAU (X3)}


Dalam rangka desentralisasi, Pemerintah Pusat melakukan transfer dana perimbangan ke Pemda diseluruh Indonesia. Transfer dana perimbangan ini mempunyai tujuan agar kesenjangan kemampuan antar daerah dapat berkurang. DAU merupakan salah satu dana perimbangan yang diperoleh Pemda dari Pemerintah Pusat melalui anggaran APBN. Dana ini ditransfer melalui APBN dan diperuntukan guna pembiayaan dan pembangunan daerah. Menurut Yovita (2011), paramaeter DAU antara lain: indeks kebutuhan daerah yang terdiri dari pengeluaran atau belanja daerah rata-rata, indeks penduduk, indeks luas daerah, indeks harga bangunan, dan indeks kemiskinan relatif. Adapun yang berasal dari penerimaan daerah adalah sebagai berikut: penerimaan daerah, indeks industri, indeks sumber daya alam (SDA), indeks sumber daya manusia (SDM). Pengukuran veriable DAU dilakukan dengan menggunakan skala rasio.

\section{DBH (X4)}

Sama halnya dengan DAU, menurut Wahyuni \& Adi (2009), DBH merupakan dana perimbangan yang dittransfer oleh Pemerintah Pusat yang dialokasikan untuk Pemprov dan Pemda di seluruh Indonesia. Namun berbeda dengan DAU, DBH dialokasikan berdasarkan angka persentase tertentu guna membiayai pengeluaran pemda. Adapun parameter DBH antara lain: DBH Pajak dan DBH Bukan Pajak (SDA). Skala rasio merupakan skala pengukuran yang digunakan untuk variabel $\mathrm{DBH}$.

\section{HASIL ANALISIS DAN PEMBAHASAN}

\section{Hasil Uji F}

\begin{tabular}{|c|c|c|c|c|c|c|}
\hline \multicolumn{7}{|c|}{$\begin{array}{c}\text { Tabel } 1 \text { : Hasil Uji F } \\
\text { ANOVA }^{\mathrm{a}}\end{array}$} \\
\hline & Model & Sum of Squares & Df & Mean Square & $\mathrm{F}$ & Sig \\
\hline \multirow{3}{*}{1} & Regression & $3,753,903,488,000$ & 4 & $938,475,872,000$ & 220.605 & $.000^{\mathrm{b}}$ \\
\hline & Residual & $336,074,483,500$ & 79 & $4,254,107,386$ & & \\
\hline & Total & $4,089,971,000$ & 83 & & & \\
\hline
\end{tabular}

Merujuk pada hasil Uji Statistik F seperti table di atas yang menunjukan bahwa nilai signifikansi $\mathrm{F}$ adalah sebesar 0,000 yang berarti nilai tersebut masih dibawah 0,05 dengan demikian maka dapat dinyatakan bahwa $\mathrm{Ho}_{5}$ tidak ditolak.

\section{Hasil Uji Hipotesis (Uji t)}

Tabel 2 : Hasil Uji t

\begin{tabular}{|c|c|c|c|c|c|c|}
\hline \multicolumn{2}{|c|}{ Model } & \multicolumn{2}{|c|}{$\begin{array}{c}\text { Unstandardized } \\
\text { Coefficients }\end{array}$} & $\begin{array}{c}\text { Standardized } \\
\text { Coefficients }\end{array}$ & \multirow{2}{*}{ T } & \multirow{2}{*}{ Sig } \\
\cline { 3 - 6 } \multicolumn{2}{c|}{} & B & Std. Error & Beta & & \\
\hline \multirow{4}{*}{1} & (Constant) & 43722.116 & 61478.081 & & 0.711 & 0.479 \\
\cline { 2 - 6 } & ECGROWTH & -3549.627 & 5241.379 & -0.023 & -0.677 & 0.500 \\
\cline { 2 - 6 } & PAD & 0.321 & 0.015 & 0.798 & 21.364 & 0.000 \\
\cline { 2 - 6 } & DAU & 0.237 & 0.026 & 0.324 & 9.127 & 0.000 \\
\hline
\end{tabular}


Vol.2, No. 1, Jan. 2019

\begin{tabular}{l|l|l|l|l|l|} 
DBH & -0.01 & 0.044 & -0.008 & -0.221 & 0.826 \\
\hline
\end{tabular}

\section{Hasil Uji Hipotesis Satu (H1)}

Dalam hipotesis pertama pada penelitian ini disebutkan adanya hubungan antara variabel Pertumbuhan Ekonomi Daerah dengan Alokasi Belanja Modal. Merujuk pada hasil uji t seperti dalam tabel di atas diketahui bahwa pengaruh Pertumbuhan Ekonomi Daerah terhadap Alokasi Belanja Modal menunjukkan nilai koefisien regresi negatif sebesar $-0,023$ ( $t_{\text {hitung }}=-0,677<t_{\text {tabel }}=1,990$ ), nilai tersebut berarti bahwa ketika Pertumbuhan Ekonomi Daerah menurun sebesar 1 satuan maka akan semakin memperbesar Alokasi Belanja Modal 0,023. Dapat dilihat bahwa nilai signifikansi dari pengaruh Pertumbuhan ekonomi terhadap belanja modal menunjukan angka 0,500 dimana nilai tersebut jauh lebih tinggi dari ambang batas yaitu 0,05 yang berarti $\mathrm{Ho}(1)$ tidak ditolak, dimana menunjukan bahwa ada pengaruh dengan arah negatif dan signifikan antara variabel bebas Pertumbuhan Ekonomi Daerah dengan variabel terikat Alokasi Belanja Modal.

\section{Hasil Uji Hipotesis Dua (H2)}

Hipotesis berikutnya meneliti hubungan antara variabel bebas PAD terhadap variabel terikat Alokasi Belanja Modal. Berdasarkan tabel hasil uji t, pengaruh variabel bebas PAD terhadap variabel terikat alokasi Belanja Modal menunjukkan nilai koefisien regresi positif sebesar 0,794 ( $t_{\text {hitung }}=21,364>t_{\text {tabel }}$ $=1,990$ ) yang berarti ketika PAD meningkat sebesar 1 satuan maka akan semakin memperbesar Alokasi Belanja Modal sebesar 0,794. Nilai signifikansi variabel bebas PAD menunjukan angka 0,000, dimana nilai signifikansi tersebut masih dibawah ambang batas yaitu 0,05. Oleh sebab itu bisa ditarik kesimpulan bahwa variabel bebas PAD mempunyai pengaruh positif dan signifikan terhadap variabel terikat alokasi Belanja Modal, sehingga Ho(2) Tidak Diterima.

\section{Hasil Uji Hipotesis Tiga (H3)}

Hipotesis berikutnya meneliti hubungan antara variabel bebas DAU terhadap variabel terikat alokasi Belanja Modal. Pengaruh variabel bebas DAU terhadap variabel terikat alokasi Belanja Modal menunjukkan nilai koefisien regresi positif sebesar 0,324 $\left(t_{\text {hitung }}=9,127>t_{\text {tabel }}=1,990\right)$ yang berarti bahwa ketika DAU meningkat sebesar 1 satuan maka akan semakin memperbesar Alokasi Belanja Modal sebesar 0,324. Nilai signifikansi menunjukan angka 0,000 dimana nilai signifikansi tersebut masih dibawah ambang batas yaitu 0,05 yang berarti bahwa Ho(3) Tidak Diterima. Oleh sebab itu bisa ditarik kesimpulan bahwa variabel bebas DAU berpengaruh positif serta signifikan terhadap variabel terikat Belanja Modal.

\section{Hasil Uji Hipotesis Empat (H4)}

Hipotesis berikutnya meneliti hubungan antara variabel bebas DBH terhadap variabel terikat alokasi Belanja Modal. Nilai koefisien regresi Pengaruh DBH terhadap Alokasi Belanja Modal menunjukkan angka negatif sebesar - 
0,008 ( $\left.\mathrm{t}_{\text {hitung }}=-0,221<\mathrm{t}_{\text {tabel }}=1,990\right)$ yang berarti bahwa ketika DBH menurun sebesar 1 satuan maka akan semakin memperbesar Alokasi Belannja Modal sebesar 0,008. Nilai signifikansi variabel DBH sebesar 0,826 dimana nilai signifikansi tersebut lebih jauh diatas ambang batas yaitu 0,05. Oleh sebab itu dapat ditarik kesimpulan bahwa variabel bebas DBH memiliki pengaruh negatif yang tidak signifikan terhadap variabel terikat Belanja Modal. Dengan demikian Ho(4) Tidak Ditolak.

\section{Pembahasan}

\section{Uji Signifikansi Simultan (Uji F)}

Penulis melakukan Uji $\mathrm{F}$ dengan tujuan guna menganalisis apakah variabel-variabel indenpenden secara simultan atau bersama-sama mempunyai pengaruh terhadap variabel terikat. Dalam Uji $\mathrm{F}$ yang diperhatikan adalah signifikansi nilai $\mathrm{F}$ pada hasil perhitungan dengan tingkat alfa $=5 \%$. Apabila nilai signifikansi uji $\mathrm{F}$ dibawah 0,05 maka dapat disimpulkan bahwa secara bersamasama seluruh variabel bebas mempunyai pengaruh terhadap variabel terikat.

Berdasarkan hasil uji regresi yang dilakukan, didapatkan nilai uji $\mathrm{F}$ yaitu signifikansi $\mathrm{F}$ diatas ambang batas yaitu 0,05 agar hipotesis dapat diterima. $\mathrm{F}_{\text {hitung }}$ sebesar 220,605 dengan signifikansi 0,000. $F_{\text {hitung }}(220,605)>F_{\text {tabel }}(2,33)$ dan nilai signifikan masih dibawah nilai probabilitas 0,05 atau nilai $0,000<0,05$, dengan demikian dapat ditarik kesimpulan bahwa seluruh variabel bebas yaitu Pertumbuhan ekonomi, PAD, DAU dan DBH secara bersama-sama atau simultan mempunyai pengaruh terhadap variabel terikat alokasi Belanja Modal.

\section{Uji Signifikansi Parsial (Uji t)}

\section{Pengaruh Pertumbuhan Ekonomi Daerah terhadap Belanja Modal}

Merujuk pada hasil penelitian yang dihasilkan, diketahui bahwa Pertumbuhan Ekonomi Daerah tidak memiliki pengaruh yang signifikan terhadap alokasi Belanja Modal. Hasil penelitian yang penulis dapatkan ini tidak sejalan dengan hasil penelitian yang digagas oeh Yovita (2011) dimana dalam penelitian yang dilakukannya menunjukan bahwa variabel bebas Pertumbuhan Ekonomi mempunyai pengaruh yang signifikan terhadap variabel terikat Belanja Modal. Sebaliknya, hasil yang penulis peroleh ini sejalan dengan hasil penelitian yang digagas oleh Darwanto (2011), Situngkir (2009) dan juga Ardhany (2011) yang membuktikan bahwa variabel bebas Pertumbuhan Ekonomi Daerah tidak memiliki pengaruh yang signifikan terhadap variabel terikat Belanja Modal.

Berdasarkan teori fiscal federalism seharusnya Pertumbuhan Ekonomi Daerah mampu mendorong pembangunan daerah yang direalisasikan melalui Belanja Modal daerah. Namun demikian penelitian ini justru membuktikan sebaliknya. Hal ini dikarenakan pada dasarnya dengan Pertumbuhan Ekonomi Daerah yang terus meningkat tiap tahunnya dengan cukup besar dan stabil, maka tentu saja akan berpengaruh terhadap perkembangan korporasi dan juga industri pada daerah tersebut. Dengan semakin berkembangnya industri maka CSR dari korporasi tersebut yang biasanya lebih banyak dialokasikan pada pembangunan infrastruktur juga semakin meningkat, sehingga Pemda tidak menjadikan Pertumbuhan Ekonomi Daerah sebagai acuan dalam penyusunan anggaran 
Belanja Modal pada APBD. Selain Pertumbuhan Ekonomi Daerah berpengaruh terhadap CSR dari industri pada Kabupaten dan Kota di Jawa Timur, variabel independen ini juga berpengaruh terhadap PAD. Dengan perkembangan industri yang baik, laba korporasi juga akan terus meningkat, dengan meningkatnya laba tersebut maka pajak yang diterima oleh Pemda dari korporasi juga ikut meningkat. Oleh karena itulah Pertumbuhan Ekonomi Daerah tidak berpengaruh secara langsung terhadap Belanja Modal melainkan secara tidak langsung yaitu melalui CSR dan juga melalui peningkatan pajak korporasi yang dalam hal ini masuk ke dalam ranah PAD dari sektor pajak pada Kabupaten/Kota di Jawa Timur.

\section{Pengaruh PAD terhadap Belanja Modal}

Merujuk pada hasil penelitian yang didapatkan diamna hasil tersebut menunjukan bahwa pengaruh yang dimiliki oleh variabel independen PAD terhadap Belanja Modal Daerah adalah pengaruh positif dan signifikan, sesuai dengan hasil penelitian Darwanto (2007), Situngkir (2009), Ardhany (2011) dan Sianipar (2011) dimana variabel PAD terbukti memiliki pengaruh positif serta signifikan terhadap Belanja Modal. Namun demikian hasil yang diperoleh dalam penelitian ini tidak sejalan dengan hasil penelitian Yovita (2011) dimana dalam penelitiannya membuktikan bahwa PAD tidak beperngaruh terhdap Belanja Modal.

Secara teori sejalan dengan adanya peningkatan PAD yang didapatkan suatu daerah maka terjadi peningkatan pula untuk alokasi Belanja Modal daerah tersebut. Hal ini disebabkan oleh kewenangan Pemda dalam menerapkan kebijakan otonomi daerah yang akan semakin luas sejalan dengan peningkatan pendapatan dalam hal ini PAD yang merupakan penerimaan yang benar-benar bersumber pada potensi daerah tersebut. Seperti yang diketahui bahwa pelaksanaan otonomi daerah mempunyai tujuan untuk mencapai peningkatan kualitas pelayanan publik dan pembangunan ekonomi. Dimana yang dimaksud dengan pelayanan publik dalam hal ini adalah sarana dan prasarana guna keperluan investasi yang direalisasikan melalui Belanja Modal. Oleh karena itu tentu saja kebijakan-kebijakan otonomi daerah berhubungan dengan pembangunan ini ekonomi ini. Dengan kata lain semakin besar PAD yang dihasilkan oleh suatu daerah maka akan semakin besar pula alokasi Belanja Modal yang dihasilkan melalui kebijakan-kebijakan otonomi daerah.

\section{Pengaruh DAU terhadap Belanja Modal}

Merujuk pada hasil penelitian yang didapatkan dimana hasil tersebut menunjukan bahwa variabel bebas DAU berpengaruh positif dan signifikan terhadap variabel terikat alokasi Belanja Modal. Hasil penelitian yang penulis peroleh ini sejalan dengan hasil peneletian yang digagas oleh Wandita (2013), Darwanto (2007), Situngkir (2009), Ardhany (2011) dan Sianipar (2011) dimana DAU terbukti mempunyai pengaruh yang signifikan. Namun, tidak sama halnya dengan hasil penelitian yang diperoleh Yovita (2011) dimana dalam penelitiannya membuktikan bahwa DAU berpengaruh negative terhadap Belanja Modal. 
Secara teori jika DAU meningkat maka diriingi dengan peningkatan Belanja Modal mengingat DAU merupakan sumber pembiayaan Pemda yang berasal dari APBN guna mengurangi ketimpangan fiscal antar daerah. Dengan adanya DAU diharapkan Pemda yang mempunyai potensi PAD kecil dapat tetap membiayai kebutuhannya dan juga tetap dapat melakukan peningkatan pelayanan publik melalui Belanja Modal.

\section{Pengaruh DBH terhadap Belanja Modal}

Merujuk pada hasil penelitian yang didapatkan dimana hasil tersebut membuktikan bahwa variabel bebas DBH tidak memiliki pengaruh yang signifikan terhadap variabel terikat Belanja Modal. Ha ini sejalan dengan hasil penelitian Sianipar (2011) dimana hasil penelitian yang dilakukannya menyatakan bahwa variabel independen DBH tidak memiliki pengaruh yang yang signifikan terhadap variabel alokasi Belanja Modal Daerah. Sebaliknya, hasil yang diperoleh penulis ini tidak sesuai dengan penelitian yang digagas oleh Wandita (2013) dimana penelitian tersebut membuktikan bahwa variabel independen DBH memiliki pengaruh yang signifikan terhadap variabel dependen alokasi Belanja Modal.

Secara teori DBH semestinya bepengaruh cukup signifikan terhadap alokasi Belanja Modal mengingat DBH adalah salah satu penerimaan daerah yang cukup potensial yang seharusnya bisa dimanfaatkan sebagai salah satu sumber pendanaan Pemda dalam melakukan pembangunan guna peningkatan pelayanan publik. Dengan adanya tambahan pendapatan daerah yang bersumber dari APBN menuntut Pemda untuk dapat meningkatkan perkonomian melalui salah satunya pembangunan sarana dan prasarana serta meningkatkan kesejahteraan masyarakat melalui pengelolaan sumber daya dengan seefektif dan seefisien mungkin. Pembangunan infrastruktur yang berkelanjutan melalui alokasi anggaran ke sektor Belanja Modal merupakan salah satu yang diharapkan dilakukan oleh Pemda dengan adanya DBH ini, namun demikian, jumlah penerimaan DBH yang relatif kecil jika dibandingkan dengan penerimaan lainnya seperti PAD dan juga DAU membuat pengaruh DBH terhadap Belanja Modal menjadi tidak signifikan. Dengan kata lain, kareana nilainya yang kecil kemudian membuat Pemda kurang mempertimbangkan DBH sebagai salah satu acuan dalam penyusuan Belanja Modal. Hal ini juga mungkin disebabkan diserapnya penerimaan DBH untuk membiayai pengeluaran daerah yang lain seperti pengeluaran rutin untuk pegawai, perawatan dll.

\section{Temuan Penelitian}

Berdasarkan hasil penelitian secara keseluruhan dan berdasarkan faktafakta yang ada, maka temuan dari Penelitian yang dilakukan adalah bahwa untuk dapat mewujudkan peningkatan pelayanan publik melalui alokasi Belanja Modal, Pemda pada Kabupaten/Kota di Jawa Timur bergantung kepada Penerimaan Daerah berupa PAD dan juga Dana Perimbangan dalam hal ini DAU. DAU adalah pemberian dari Pemerintah Pusat sehingga tidak dapat selalu diandalkan oleh Pemda untuk alokasi Belanja Modal. Sedangkan PAD sifatnya sangat flexible dimana penerimaan tersebut dapat digunakan untuk membiayai Belanja 
Operasional maupun Belanja Modal. Berdasarkan Otonomi Daerah dengan asas kemandirian, semestinya Pemda tidak terlalu mengandalkan DAU sebagai acuan dalam penyusunan Belanja Modal. Pemda semestinya berusaha untuk dapat mengoptimalkan dan juga menggali semua sumber-sumber Penerimaan daerah dalam hal ini PAD. Karena dengan meningkatkan PAD Pemda dapat meningkatkan Belanja Modal yang sangat penting untuk peningkatan pelayanan publik dan juga untuk dapat menarik investor agar dapat berinvestasi di daerah tersebut.

\section{PENUTUP}

\section{Kesimpulan}

Merujuk pada serangkain kajian, hasil yang diperoleh serta pembahasan yang sudah dijabarkan, sehinnga kemudian dapat ditarik kesimpulan sebagaimana pernyataan berikut ini: (1) variabel Pertumbuhan Ekonomi dan DBH terbukti tidak mempunyai pengaruh yang signifikan terhadap Belanja Modal pada Pemda Kabupaten/Kota di Jawa Timur. (2) PAD dan DAU terbukti mempunyai pengaruh yang signifikan terhadap Belanja Modal pada Pemda Kabupaten/Kota di Jawa Timur. (3) Secara simultan, Pertumbuhan Ekonomi Daerah, PAD, DAU dan DBH terbukti berpengaruh signifikan terhadap Belanja Modal pada Pemda Kabupaten/Kota di Jawa Timur.

Dalam tujuannya untuk dapat meningkatkan Belanja Modal Pemda Kabupaten/Kota di Jawa Timur semestinya mengoptimalkan dan menggali lagi potensi basis penerimaan daerah dalam hal ini PAD, dimana PAD sifatnya flexible dalam penggunaannya.

\section{Saran}

Merujuk pada hasil dan temuan yang diperoleh, maka penulis ingin memberikan saran sebagaimana berikut ini: bagi Pemda agar dapat lebih meningkatan Belanja Modal guna meningkatkan pelayanan publik, serta agar lebih mengoptimalkan PAD sebagai tumpuan dan acuan guna penyusunan alokasi Belanja Modal. Dari data Realiasai APBD Pemda Kabupaten/Kota di Jawa Timur periode 2011-2014 terlihat PAD yang terbesar berasal dari Pajak Daerah, Retribusi Daerah, Lain-lain PAD yang sah dan yang terkecil adalah Hasil Pengelolaan Kekayaan Daerah yang dipisahkan. Diharapkan Pemda dapat menggali dan meningkatkan lagi PAD yang bersumber pada Pengelolaan Kekayaan Daerah tersebut. Selain itu agar dapat memperhatikan juga DBH meskipun nilainya tidak terlalu besar, namun setidaknya dapat digunakan untuk dapat meningkatkan Belanja Modal daerah tersebut. Untuk peneliti berikutnya diharapkan menggunakan variabel yang lebih bervariasi, dengan memperbanyak jumlah variabel independen lain baik ukuran-ukuran atau jenis-jenis penerimaan pemerintah daerah lainnya seperti penerimaan pembiayaan pada APBD atas SILPA tahun anggaran sebelumnya. Mengingat sangat menariknya Pertumbuhan Ekonomi Daerah di Jawa Timur, agar dapat lebih fokus terhadap variabel tersebut, serta menggali tentang CSR dari perusahaan-perusahaan di Jawa Timur karena 
kemungkinan besar Pertumbuhan Ekonomi Daerah di Jawa Timur sangat mempengaruhi CSR industri yang ada di daerah tersebut. Dimana CSR tersebut juga turut berperan dalam pembangunan di Jawa Timur.

Selain itu diharapkan agar dapat menggunakan data terbaru dari tahun 2015/2016 mengingat tahun 2016 terjadi perubahan kepemimpinan dengan adanya Pemilihan Umum Kepala Daerah dimana terdapat beberapa Kepala Daerah Muda yang mempunyai program Padat Karya guna membangun daerahnya bukan hanya dari segi infrastruktur namun juga dari segi SDM yang dimilikinya. Disamping itu, sampel penelitian juga dapat diperluas mengingat begitu luasnya wilayah di Indonesia ini, juga rentang periode agar dapat ditambah guna memperbanyak perbandingan anatara daerah yang satu dengan daerah yang lainnya.

\section{REFERENSI}

Ardhani, Pungky. (2011). Pengaruh Pertumbuhan Ekonomi, Pendapatan Asli Daerah, Dana Alokasi Umum, Dan Dana Alokasi Khusus Terhadap Pengalokasian Anggaran Belanja Modal (Studi Pada Pemerintah Kabupaten/Kota Di Jawa Tengah). Skripsi. Semarang: Universitas Diponegoro.

Boediono. (2009). Teori Pertumbuhan Ekonomi. Yogyakarta: BPFE Yogyakarta.

Darwanto \& Yulia Yustikasari. (2007). Pengaruh Pertumbuhan Ekonomi, Pendapatan Asli Daerah, Dana Alokasi Umum Terhadap Pengalokasian Belanja Modal. Simposium Nasional Akuntansi X Makasar 26-28 Juli 2007. (2009). Akuntansi Sektor Publik Akuntansi Keuangan Daerah. Jakarta:

Salemba Empat.

http://www.djpk.depkeu.go.id. Diakses pada 25 Mei 2017. Pukul 17.00

http://jatim.bps.go.id. Diakses pada 25 Mei 2017. Pukul 17.15

Maharani, Mayzestika. (2010). Pengaruh Pertumbuhan Ekonomi, Pendapatan Asli Daerah, dan Dana Alokasi Umum, Terhadap Belanja Modal Pada Pemerintah Daerah se Jawa Tengah. Skripsi. Universitas Negeri Semarang. PP No. 55 Tahun 2005 tentang Dana Perimbangan.

PP No. 58 Tahun 2005 tentang Pengelolaan Keuangan Daerah.

Putro, Nugroho Suratno. (2010). Pengaruh Pertumbuhan Ekonomi, Pendapatan Asli Daerah dan Dana Alokasi Umum Terhadap Pengalokasian Anggaran Belanja Modal (Studi Kasus pada Kabupaten/kota di Provinsi Jawa Tengah). Diponegoro Jurnal Of Accounting. Semarang: UNDIP.

Ririn, Gurning. (2011). Tugas Dana Alokasi Umum dan Laporan Realisasi Anggaran. http://www.edublogs.riringurning.com. Diakses pada 4 januari 2013. Pukul 20.30.

Saragih, Juli Panglima. (2003). Desentralisasi Fiskal dan Keuangan Daerah Dalam Otonomi. Cetakan Pertama, Ghalia Indonesia, Jakarta.

Sianipar, Eva Septriani. (2011). Analisis Pengaruh Pendapatan Asli Daerah (PAD) Dan Dana Perimbangan Terhadap Pengalokasian Belanja Modal 
Pada Kabupaten/Kota Di Sumatera Utara. Skripsi. Universitas Sumatera Utara.

Sirait, Robby Alexander. (2009). Desentralisasi fiskal Dana Alokasi Umum. http://www.bloggersumut.robbyalexandersirait.com. Diakses pada 19 desember 2012. Pukul 19.00.

Syafitri, Irma. (2009). Pengaruh Pertumbuhan Ekonomi, Pendapatan Asli Daerah, dan Dana Alokasi Umum, Terhadap Pengalokasian Anggaran Belanja Modal Pada Pemerintah Kabupaten/Kota Di Sumatera Utara. Skripsi. Universitas Sumatera Utara.

Sugiyono, (2008). Metodologi Penelitian Kuantitatif, Kualitatif, dan $R \& D$. Bandung: Alfabeta.

Undang-undang No.33 Tahun 2004 tentang Perimbangan Keuangan Antara Pemerintah Pusat dan Pemerintah daerah.

Undang-undang No. 36 Tahun 2008 tentang Pajak Penghasilan.

Wahyuni dan Priyo Hari Adi. (2009). Analisis Pertumbuhan Dan Kontribusi Dana Bagi Hasil Terhadap Pendapatan Daerah (Studi Pada Kabupaten/Kota Se Jawa-Bali). National Conference UKWMS Surabaya.

Yovita, Farah Marta. (2011). Pengaruh Pertumbuhan Ekonomi, Pendapatan Asli Daerah dan Dana Alokasi Umum Terhadap Pengalokasian Anggaran Belanja Modal (Studi Empiris pada Pemerintah Provinsi Se Indonesia Periode 2008 - 2010). Diponegoro Jurnal Of Accounting. Semarang: UNDIP. 